\title{
Antichlamydial Sterol from the Red Sea Sponge Callyspongia aff. implexa
}

Authors

Affiliations
Usama Ramadan Abdelmohsen ${ }^{1,5}$, Cheng Cheng ${ }^{1}$, Anastasija Reimer ${ }^{2}$, Vera Kozjak-Pavlovic ${ }^{2}$, Amany K. Ibrahim ${ }^{3}$, Thomas Rudel ${ }^{2}$, Ute Hentschel ${ }^{1}$, RuAngelie Edrada-Ebel ${ }^{4}$, Safwat A. Ahmed ${ }^{3}$

The affiliations are listed at the end of the article

\author{
Key words \\ - Callyspongia aff. implexa \\ - Callyspongiidae \\ - sponges \\ - Red Sea \\ - sterol \\ - polyacetylene \\ - Chlamydia trachomatis
}

\begin{abstract}
received Sept. 12, 2014
revised January 10, 2015

accepted January 24, 2015
\end{abstract}

\section{Bibliography}

Dol http://dx.doi.org/

10.1055/s-0035-1545721

Published online March 17, 2015

Planta Med 2015; 81: 382-387

(c) Georg Thieme Verlag KG

Stuttgart · New York .

ISSN 0032-0943

\section{Correspondence}

Safwat A. Ahmed

Department of Pharmacognosy

Faculty of Pharmacy

Suez Canal University

Ring Road Street

Ismailia 41522

Egypt

Phone: + 201092638387

Fax: + 20643230741

safwat_aa@yahoo.com

\section{Correspondence}

RuAngelie Edrada-Ebel

Strathclyde Institute of

Pharmacy and Biomedical

Sciences

University of Strathclyde

The John Arbuthnott Building

161 Cathedral Street

Glasgow G40 NR

UK

Phone: + 441415485968

Fax: + 441415522562

ruangelie.edrada-ebel@

strath.ac.uk

\section{Abstract \\ $\nabla$}

Marine sponges are rich sources of natural products exhibiting diverse biological activities. Bioactivity-guided fractionation of the Red Sea sponge Callyspongia aff. implexa led to the isolation of two new compounds, 26,27-bisnorcholest-5,16dien-23-yn-3 $\beta, 7 \alpha$-diol, gelliusterol E (1) and $\mathrm{C}_{27^{-}}$ polyacetylene, callimplexen A (2), in addition to the known compound $\beta$-sitosterol (3). The structures of the isolated compounds were determined by $1 \mathrm{D}$ - and 2D-NMR techniques as well as high-

\section{Introduction}

$\nabla$

The lack of physical defences in marine sponges makes them susceptible to marine predators such as fish, turtles, and invertebrates. Thus, it is frequently speculated that sponges have developed a wide range of defensive compounds to deter predators [1,2]. They also use their defensive chemicals to keep the offspring of small plants and animals (fouling organisms) from settling onto their outer surfaces $[3,4]$. These sessile animals are prolific producers of a huge diversity of secondary metabolites that have been discovered over the past years [3,5-8]. The genus Callyspongia belongs to the order Haplosclerida, family Callyspongiidae. Members of this genus have provided polyacetylenic compounds including polyacetylenic alcohols [9], sulphate [10], hydrocarbons [11], and amides with diverse activities including antifouling and cytotoxic activities [12]. Moreover, steroidal anti-inflammatory compounds have also been reported from this genus [13].

The gram-negative obligate intracellular human pathogen Chlamydia trachomatis is one of the main causative agents of sexually transmitted diseases and infections of the upper inner eyelid (trachoma) $[14,15]$. The ocular disease is caused resolution tandem mass spectrometry and by comparison to the literature. The three compounds (1-3) were tested against Chlamydia trachomatis, an obligate intracellular gram-negative bacterium, which is the leading cause of ocular and genital infections worldwide. Only gelliusterol E (1) inhibited the formation and growth of chlamydial inclusions in a dose-dependent manner with an $\mathrm{IC}_{50}$ value of $2.3 \mu \mathrm{M}$.

Supporting information available online at http://www.thieme-connet.de/products

by $C$. trachomatis serovar A to $C$ and, if untreated, may result in blindness; it is thus a major problem in developing countries with poor health care [ 16 , 17]. C. trachomatis serovars $D$ to $K$ are responsible for infection of the genital tract, which may lead to pelvic inflammatory disease and infertility, whereas serovars L1, L2, and L3 cause lymphogranuloma venereum, a sexually transmitted infection of the lymph nodes $[18,19]$. Chlamydia features a biphasic developmental cycle that occurs in a specialized vacuole, the so-called inclusion. Upon infection, Chlamydia suppresses host cell apoptosis to escape the immune response [20]. The infection is initiated by the elementary bodies (EBs), an infectious and metabolically inert chlamydial form. Within the inclusion, EBs differentiate into a replicative form, named reticulate bodies (RBs). At the end of the developmental cycle, a differentiation of the RBs back to the EBs occurs, thus enabling the new progeny to be released and to initiate a new infectious cycle. RBs are also able to convert to a persistent non-replicative state, which leads to a long-term relationship with the host cell [21]. Reinfection and persistence are the reason for prolonged therapy of chlamydial infections, in which different antibiotics are used, including tetracyclines, azithromycin, or erythromycin. An incompetent administra- 
tion of antimicrobial therapy is known to induce persistence of Chlamydia [22]. Additionally, a vaccine is not available against human Chlamydia, which makes it an interesting model organism in search for novel classes of antimicrobial agents. There are few examples of natural products that were found to inhibit chlamydial infections. One is betulin derivatives, of which 32 were examined in vitro against Chlamydia pneumonia. Only betulin dioxime was highly active with an MIC value of $1 \mu \mathrm{M}$ against strain C. pneumonia CWL-029 [23]. The novel macrocyclic lactones, saccharocarcins A and B, were isolated from the actinomycete Saccharothrix aerocolonigenes subsp. antibiotica SCC 1886 and were active against $C$. trachomatis serotype $\mathrm{H}$ at an MIC value of $0.5 \mu \mathrm{g} / \mathrm{mL}$ [24].

In the present study, we aimed to identify new antichlamydial natural products from Red Sea sponges. We herein report the isolation and structure elucidation of two new metabolites, 26,27bisnorcholest-5,16-dien-23-yn-3 $\beta, 7 \alpha$-diol, gelliusterol E (1) and $\mathrm{C}_{27}$-polyacetylene, callimplexen A (2), along with the previously known inactive metabolite $\beta$-sitosterol (3), for the first time from Callyspongia aff. implexa. The metabolites were tested for inhibitory effects on the growth of $C$. trachomatis, and gelliusterol $\mathrm{E}$ was found to affect the formation and growth of chlamydial inclusions in a dose-dependent manner. To our knowledge, this is the first report of natural products from this sponge species.

\section{Results and Discussion}

$\nabla$

In our continuing search for new antichlamydial natural products from marine sponges, the methanol-dichloromethane $(1: 1)$ extract of the lyophilized Red Sea sponge $C$. aff. implexa showed activity against $C$. trachomatis. A bioactivity-guided assay was performed to further isolate and characterize the antichlamydial compounds. The crude extract was then fractionated by gel filtration on Diaion HP20 eluting with increasing concentrations of methanol in water. Finally, purification of the bioactive fraction was then accomplished on normal phase HPLC using a dichloromethane (DCM) and ethyl acetate (EtOAc) mixture to afford three compounds, 1-3.

Compound 1 was isolated as white powder with the molecular formula of $\mathrm{C}_{25} \mathrm{H}_{36} \mathrm{O}_{2}$, corresponding to eight degrees of unsaturation. ${ }^{1} \mathrm{H}$ and ${ }^{13} \mathrm{C}$ NMR data for $\mathbf{1}$ ( 0 Table $\mathbf{1}$ ) were almost identical to those for gelliusterol A (4), which was previously isolated from the marine sponge Gellius sp. [25]. The two main differences between the ${ }^{13} \mathrm{C}$ NMR chemical shifts for $\mathbf{1}$ and $\mathbf{4}$ were observed at $\mathrm{C}-16\left(\delta_{\mathrm{C}} 114.2\right)$ and $\mathrm{C}-17\left(\delta_{\mathrm{C}} 147.0\right)$, indicating the presence of a trisubstituted double bond instead of methine and methylene carbons at $\mathrm{C}-17$ and $\mathrm{C}-16$. The absolute configuration at C-3 is assumed to be $S$, the same as gelliusterol A (4) [25]. The relative stereochemistry at other centers was assigned on the basis of a 2D NOESY experiment. The NOESY spectrum showed correlations of $\mathrm{H}-3$ with $\mathrm{H}-9$ and $\mathrm{H}-14$ but no apparent correlations with $\mathrm{H}-7, \mathrm{H}-8, \mathrm{H}_{3}-18$, and $\mathrm{H}_{3}-19$ were observed, indicating that $\mathrm{H}-3$, $\mathrm{H}-9$, and $\mathrm{H}-14$ were on the same side of the molecule in the $\alpha$-orientation while $\mathrm{H}-7, \mathrm{H}-8, \mathrm{H}_{3}-18$, and $\mathrm{H}_{3}-19$ were in the opposite direction in the $\beta$-orientation. Similar NMR shifts of C-20 with gelliusterol $\mathrm{A}$ and other sterols show relative configurations at $\mathrm{C}-20$ [25]. The trivial name gelliusterol $\mathrm{E}$ was assigned to the new sterol 1: 26,27-bisnorcholest-5,16-dien-23-yn-3 $\beta, 7 \alpha$-diol. Compound $\mathbf{2}$ was isolated as a yellow oil with the predicted formula of $\mathrm{C}_{27} \mathrm{H}_{38}$ (nine degrees of unsaturation). The ${ }^{1} \mathrm{H}$ NMR spectrum of $\mathbf{2}$ ( $\bullet$ Table 2 ) showed resonances for one terminal methyl
Table $1{ }^{1} \mathrm{H}(400 \mathrm{MHz})$ and ${ }^{13} \mathrm{C}(100 \mathrm{MHz})$ NMR data of compound 1 in $\mathrm{CDCl}_{3}$.

\begin{tabular}{|c|c|c|c|}
\hline Position & ${ }^{1} \mathrm{H}$ & $\cos Y$ & ${ }^{13} \mathrm{C}$ \\
\hline \multirow[t]{2}{*}{1} & $1.11, \mathrm{~m}$ & 2 & 37.0 \\
\hline & $1.87, \mathrm{~m}$ & & \\
\hline \multirow[t]{2}{*}{2} & $1.49, \mathrm{~m}$ & 1 & 31.5 \\
\hline & $1.84, \mathrm{~m}$ & & \\
\hline 3 & $3.58, \mathrm{~m}$ & 2,4 & 72.0 \\
\hline 4 & $2.34, \mathrm{~m}$ & 3 & 41.4 \\
\hline 5 & & & 147.7 \\
\hline 6 & $5.61, d$ & 7 & 124.5 \\
\hline 7 & 3.85 , br s & 6,8 & 65.9 \\
\hline 8 & $1.49, \mathrm{~m}$ & 7 & 39.1 \\
\hline 9 & $0.91, \mathrm{t}$ & & 44.0 \\
\hline 10 & & & 38.0 \\
\hline 11 & $1.49, \mathrm{~m}$ & & 21.6 \\
\hline \multirow[t]{2}{*}{12} & $1.11, \mathrm{~m}$ & & 40.9 \\
\hline & $2.00, \mathrm{~m}$ & & \\
\hline 13 & & & 45.6 \\
\hline 14 & $1.08, \mathrm{~m}$ & 15 & 47.2 \\
\hline 15 & $2.05, \mathrm{~m}$ & 16 & 25.0 \\
\hline 16 & $5.15, d$ & 15 & 114.2 \\
\hline 17 & & & 147.0 \\
\hline 18 & $0.68, d$ & & 12.0 \\
\hline 19 & $1.00, \mathrm{~s}$ & & 18.0 \\
\hline 20 & $1.5, \mathrm{~m}$ & 21,22 & 35.8 \\
\hline 21 & $1.01, \mathrm{~s}$ & & 19.0 \\
\hline 22 & $2.33, d$ & 20 & 26.2 \\
\hline 23 & & & 78.9 \\
\hline 24 & & & 77.7 \\
\hline 25 & $1.69, \mathrm{~m}$ & & 3.3 \\
\hline
\end{tabular}

at $\delta_{\mathrm{H}} 0.87$ and one terminal acetylene at $\delta_{\mathrm{H}} 3.01(\mathrm{~s}, \mathrm{H}-1)$. The IR spectrum also established the presence of terminal acetylenic $\mathrm{C}-\mathrm{H}$ and the $\mathrm{C} \equiv \mathrm{C}$ bands [26]. Two olefinic protons for a $Z$-double bond at C-3/C-4 $\left(J^{3,4} 10.8 \mathrm{~Hz}\right)$, together with signals for nine methylenes, accounted for the remaining protons in the molecule. Multiplets at $\delta_{\mathrm{H}} 2.15$ and 2.33 were assigned to alkyl protons next to the olefinic group. The ${ }^{13} \mathrm{C}$ NMR spectrum of $\mathbf{2}$, combined with HMQC experiment results ( 0 Table 2 ), showed resonances for eight acetylenic carbons $\left[\delta_{C} 81.7,80.4,80.4\right.$ (overlapped C)], two sp2 carbons [ $\delta_{\mathrm{C}} 145.2$ and 108.8], and sixteen methylene carbons. Interpretation of the ${ }^{1} \mathrm{H}-{ }^{1} \mathrm{H}$ COSY and $\mathrm{HMBC}$ spectra led us to the assembly of the C-1/C-7 unit. The quaternary acetylenic carbons were established from the HMBC experiment as correlations between $\mathrm{H}-1 / \mathrm{C}-2\left({ }^{2} J_{\mathrm{CH}}\right), \mathrm{H}-3 / \mathrm{C}-1\left({ }^{3} J_{\mathrm{CH}}\right), \mathrm{H}-4 / \mathrm{C}-2$ $\left({ }^{3} J_{\mathrm{CH}}\right)$, and $\mathrm{H}-1 / \mathrm{C}-2\left({ }^{2} \mathrm{~J}_{\mathrm{CH}}\right)$, determining the location of the terminal acetylene and olefinic carbons. Further support for the C-1/C11 unit came from comparing the chemical shifts of $\mathbf{2}$ with aikupikanyne B isolated from the Red See sponge Callyspongia sp. whose ${ }^{13} \mathrm{C}$ and ${ }^{1} \mathrm{HNMR}$ spectra are very similar [10]. Significant fragmentation ion peaks $(\mathrm{m} / \mathrm{z} 131,145,173,211,277$, and 333) in the LRMS confirmed the position of the isolated triple bond and supported the structure of $\mathbf{2}$ ( $\mathbf{0}$ Fig. $\mathbf{1}$ ). Also, a combination of COSY and HMBC experiments and comparison with the spectra of callypentayne, which was isolated from the Japanese sponge Callyspongia sp. [27], enabled us to establish the structure of $\mathbf{2}$. The name callimplexen $\mathrm{A}$ was assigned to the new $\mathrm{C}_{27^{-}}$ polyacetylene. More functionalized $C_{27}$-polyacetylenes have been isolated before from a Caribbean sponge, Petrosia sp. [28]. The molecular ion peak of the third compound (3) was afforded by GC-EIMS as $\mathrm{m} / z 414.34$ with the predicted formula of 
Table $2{ }^{1} \mathrm{H}(400 \mathrm{MHz})$ and ${ }^{13} \mathrm{C}(100 \mathrm{MHz})$ NMR data of compound 2 in $\mathrm{CDCl}_{3}$.

\begin{tabular}{|c|c|c|}
\hline Position & ${ }^{\mathbf{1}} \mathbf{B}$ & ${ }^{13} \mathbf{C}$ \\
\hline 1 & $3.01, \mathrm{~s}$ & 81.7 \\
\hline 2 & & 80.4 \\
\hline 3 & $5.47, \mathbf{d}$ & 108.8 \\
\hline 4 & $5.97, \mathrm{~m}$ & 145.2 \\
\hline 5 & $2.15, \mathrm{~m}$ & 32.0 \\
\hline 6 & $1.54, \mathrm{~m}$ & 19.3 \\
\hline 7 & $2.33, \mathrm{~m}$ & 32.0 \\
\hline 8 & & 80.4 \\
\hline 9 & & 80.4 \\
\hline 10 & $2.33, \mathrm{~m}$ & 32.0 \\
\hline 11 & $1.58, \mathrm{~m}$ & 19.3 \\
\hline 12 & $1.58, \mathrm{~m}$ & 19.3 \\
\hline 13 & $2.33, \mathrm{~m}$ & 32.0 \\
\hline 14 & & 80.4 \\
\hline 15 & & 80.4 \\
\hline 16 & $2.36, \mathrm{~m}$ & 32.0 \\
\hline 17 & $1.54, \mathrm{~m}$ & 19.3 \\
\hline 18 & $1.54, \mathrm{~m}$ & 19.3 \\
\hline 19 & $2.36, \mathrm{~m}$ & 32.0 \\
\hline 20 & & 80.4 \\
\hline 21 & & 80.4 \\
\hline 22 & $2.33, \mathrm{~m}$ & 32.0 \\
\hline 23 & $1.52, \mathrm{~m}$ & 32.0 \\
\hline $24-26$ & $1.25, \mathrm{~m}$ & 32.0 \\
\hline 27 & $0.87, \mathrm{~m}$ & 14.8 \\
\hline
\end{tabular}

$\mathrm{C}_{29} \mathrm{H}_{50} \mathrm{O}$ and identified as sitosterol from the online NIST11 database. By comparing the ${ }^{1} \mathrm{H}$ and ${ }^{13} \mathrm{C}$ spectra with those of $\beta$-sitoste$\operatorname{rol}(\geq 97 \%$, Sigma-Aldrich), the compound was confirmed as $\beta$-sitosterol.

Compounds 1-3 were tested for their antichlamydial activity using epithelial HeLa cells with $C$. trachomatis as a model system. Only gelliusterol E had an effect on Chlamydia infection, while at the same time, it did not have an adverse effect on host cells ( Fig. 2a,b). Gelliusterol E inhibited the formation and growth of chlamydial inclusions in a dose-dependent manner. HeLa cells were infected in the presence of $1.6,8.0$, and $40.0 \mu \mathrm{M}$ of gelliusterol $\mathrm{E}$. The higher the concentration of the compound, the smaller the inclusion size ( $\bullet$ Fig. $\mathbf{2 b}$ ). However, there was no fragmentation of inclusions as had been observed with other antichlamydial agents (data not shown). At the highest concentration of $40 \mu \mathrm{M}$, no inclusions could be observed at all, analogous to the effect of the tetracycline (Tet) control ( Fig. 2 a). The $\mathrm{IC}_{50}$ value, defined as the concentration at which the size of chlamydial inclusion relative to the cell surface was reduced by $50 \%$, was $2.34 \pm 0.22 \mu \mathrm{M}$ ( Fig. $2 \mathrm{c}$ ).

The inhibitory effect of gelliusterol $\mathrm{E}$ was even greater when we addressed the ability of $C$. trachomatis to create viable progeny under the treatment with gelliusterol E ( Fig. 3a,b). An EB progeny assay was performed in order to analyze the effect of the compound on the developmental cycle of Chlamydia. HeLa cells were infected with $C$. trachomatis in the presence of the DMSO and Tet controls and in the presence of $1.6 \mu \mathrm{M}, 8 \mu \mathrm{M}$, and $40 \mu \mathrm{M}$ gelliusterol E. For the analysis of the EB primary infection, the infected cells were harvested after $24 \mathrm{~h}$. A parallel set of samples was infected for $48 \mathrm{~h}$, with the EB progeny being used to infect new cells without any treatment, and these cells were harvested after $24 \mathrm{~h}$. A Western blot was performed with the cell lysates using an anti- $\beta$-tubulin antibody as a loading control. For determi-

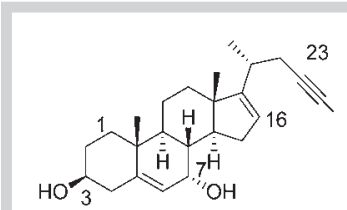

(1)

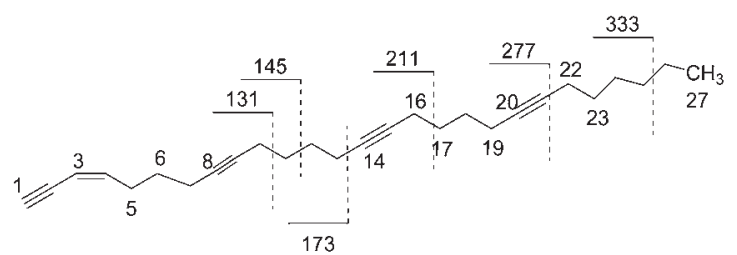

(2)

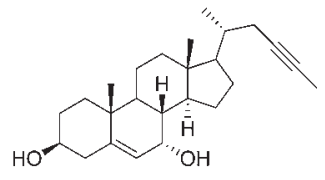

(4)

Fig. 1 Structures of isolated compounds 1-3 and gelliusterol A (4).

nation of the chlamydial content, an antibody was applied against the chlamydial protein OmpA. As suggested by our previous results, the compound affected the primary infection in a dose-dependent manner - the higher the concentration, the less the chlamydial protein OmpA was detected. However, gelliusterol E also affects the progeny, which is less infectious. At a concentration of $40 \mu \mathrm{M}$, practically no viable progeny was formed. Thus, the compound not only inhibits the formation but also affects the developmental cycle of Chlamydia. C. trachomatis is known to acquire lipids necessary for its growth, including cholesterol, from the host cell [29]. Due to the structural similarity of gelliusterol E to cholesterol, we speculate that the substance could be in some way inhibiting the lipid acquisition of the chlamydial inclusion and therefore inhibiting its growth. Recent reports, however, suggest that $C$. trachomatis can successfully grow in cells defective in cholesterol biosynthesis [30], but it does not exclude the possibility that gelliusterol $\mathrm{E}$ is being recruited to the inclusion, similarly to cholesterol, where it could affect the stability and growth of the inclusion membrane. Future experiments will be performed to explore the exact mechanism of action.

In conclusion, two new metabolites, 26,27-bisnorcholest-5,16dien-23-yn-3 $\beta, 7 \alpha$-diol, gelliusterol E (1) and $C_{27}$-polyacetylene, callimplexen A (2), along with the previously known metabolite $\beta$-sitosterol (3) were isolated and identified from the Red Sea sponge Callyspongia aff. implexa. An important finding from this study is the potent antichlamydial activity of gelliusterol $\mathrm{E}$ against $C$. trachomatis. This finding highlights the potential of marine sponges for novel bioactivities for biomedical applications. 
(a)
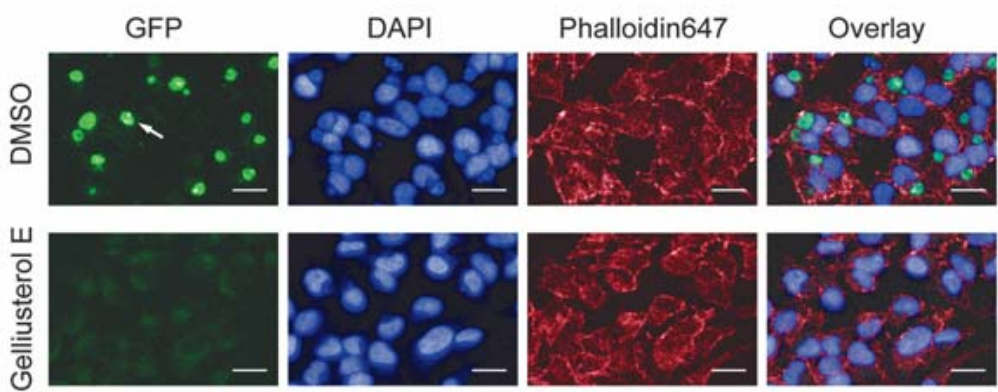

(b)

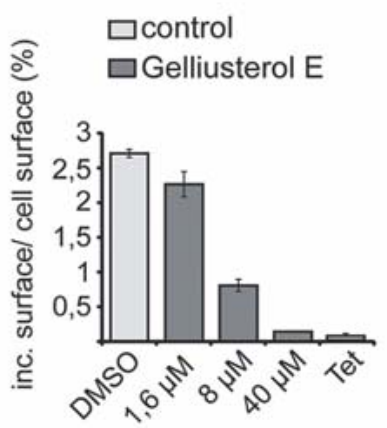

(c)
Fig. 2 Gelliusterol E inhibited Chlamydia infection in a dose-dependent manner. a HeLa cells were infected with $C$. trachomatis expressing GFP at a $\mathrm{MOI} 1$ for $24 \mathrm{~h}$ in the presence of DMSO and $40 \mu \mathrm{M}$ gelliusterol $\mathrm{E}$. The chlamydial inclusions appear in the green channel (arrow), cell nuclei were stained with DAPI (blue channel), and the actin cytoskeleton with Phalloidin647 (red channel). Scale bars are $25 \mu \mathrm{m}$. b The graph represents mean values \pm SD of the surface of inclusions relative to the cell surface from six independent repetitions of the experiment. c IC $\mathrm{C}_{50}$ of gelliusterol $\mathrm{E}$. (Color figure available online only.) (a)

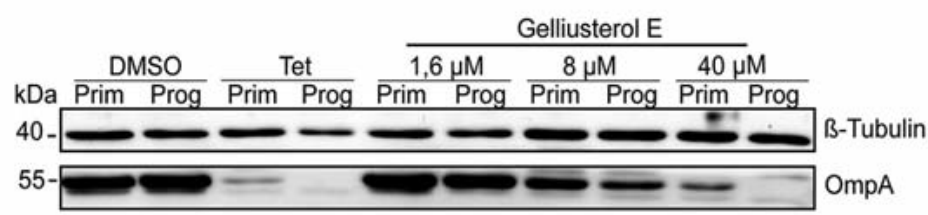

(b)

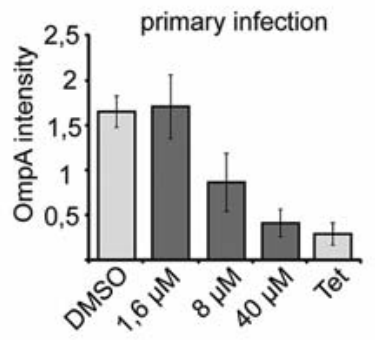

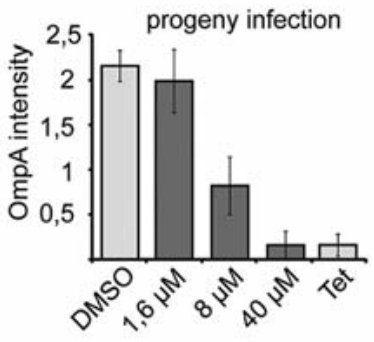

Fig. 3 Gelliusterol E affects the primary and progeny chlamydia infection in a dose-dependent manner. a Western blot resulting from the EB progeny assay showing the EB primary (Prim) and progeny (Prog) infection of $C$. trachomatis in the presence of the DMSO and tetracycline (Tet) controls and depicted gelliusterol E concentrations. b The signals from Western blot as described in a were quantified using Image J. The graph represents mean values \pm SD from three independent experiments.

\section{Materials and Methods}

\section{Biological material, collection, and identification}

C. aff. implexa, Topsent 1892, was collected using Scuba at depths of 15-20 m from the Red Sea (Safaga, Egypt). The sponge material was frozen immediately and kept frozen at $-20^{\circ} \mathrm{C}$ until processed. The sponge was identified by Dr. R.W.M. van Soest (Faculty of Science, Zoological Museum, Amsterdam). A voucher specimen was deposited in the herbarium section of the Pharmacognosy Department (Faculty of Pharmacy, Suez Canal University, Ismailia, Egypt) under registration number SAA-12 and at the Zoological Museum of the University of Amsterdam under registration No. ZMAPOR. 19758.

\section{$\square$ control}

$\square$ Gelliusterol E

\section{Extraction and isolation of compounds from Callyspongia aff. implexa extract}

After freeze-drying, the sponge material $(0.7 \mathrm{~kg})$ was extracted with methanol-dichloromethane $(1: 1)(4 \mathrm{~L} \times 4)$ at room temperature to yield $65 \mathrm{~g}$ of crude extract. The extract was fractionated by gel filtration on a Diaion HP20 open column $(100 \mathrm{~cm}$ À $10 \mathrm{~cm}$; the volume of the column was $7 \mathrm{~L}$ ) using a gradient of $\mathrm{H}_{2} \mathrm{O}(\mathrm{A})$ and $\mathrm{MeOH}(B)(0-100 \%$ B). Similar fractions were grouped together, then concentrated under reduced pressure, and monitored by TLC using silica gel $\mathrm{G}_{60} \mathrm{~F}_{254}$ plates to give three fractions, F1 $(23 \mathrm{~g})$, F2 (16 g) and F3 (20 g). Fraction 2 showed a potential inhibitory effect against $C$. trachomatis and was subjected to a flash silica gel column (I.D. $\times$ L $5 \mathrm{~cm} \times 25 \mathrm{~cm}$ ) with acetone and $\mathrm{MeOH}$ to yield fractions F4-15. Only fraction $4(650 \mathrm{mg})$ showed a potential inhibitory effect against $C$. trachomatis. Further separation was performed on a semipreparative normal-phase HPLC column [5 $\mu \mathrm{m}, 250 \times 10 \mathrm{~mm}$ (i.d.); Luna, Phenomenex, USA] using a DCM 
and EtOAc solvent mixture (70\% DCM : EtOAc to 100\% EtOAc over $40 \mathrm{~min}$ at a flow rate of $5 \mathrm{~mL} / \mathrm{min}$ ), giving three compounds, 1 (11 mg, Rt = 14), 2 ( $5 \mathrm{mg}, \mathrm{Rt}=9$ ) and 3 (38 mg, Rt = 17).

Gelliusterol E (1, purity 95\%): white powder, amorphous powder; IR (film) $v_{\max } 2245,3313 \mathrm{~cm}^{-1}$; ${ }^{1} \mathrm{H}$ NMR $\left(\mathrm{CDCl}_{3}, 400 \mathrm{MHz}\right)$ and ${ }^{13} \mathrm{C}$ $\operatorname{NMR}\left(\mathrm{CDCl}_{3}, 100 \mathrm{MHz}\right)$, ๑ Table 1; HREIMS m/z 367.2638 [M - H] ${ }^{-}$ (calcd. for $\mathrm{C}_{25} \mathrm{H}_{35} \mathrm{O}_{2}, 367.2637$ ).

Callimplexen A (2, purity 96\%): yellow oil; IR (film) $v_{\max } 2230$, $3298 \mathrm{~cm}^{-1} ; \lambda_{\max }(\log \varepsilon): 205,255 ;{ }^{1} \mathrm{H}$ NMR $\left(\mathrm{CDCl}_{3}, 400 \mathrm{MHz}\right)$ and ${ }^{13} \mathrm{C} \mathrm{NMR}\left(\mathrm{CDCl}_{3}, 100 \mathrm{MHz}\right)$, @ Table 2; HREIMS m/z 361.2859 [M $\mathrm{H}]^{-}$(calcd. for $\mathrm{C}_{27} \mathrm{H}_{37}, 361.2895$ ). Combustion analysis showed $89.41 \%$ carbon and $10.59 \%$ hydrogen.

\section{Cell culture}

HeLa cells were cultured in RPMI 1640 (Gibco) media supplemented with $10 \%(\mathrm{v} / \mathrm{v})$ h.i. FBS (Biochrom) at $37^{\circ} \mathrm{C}$ under $5 \%$ $\mathrm{CO}_{2}$. C. trachomatis $\mathrm{C} 2(\mathrm{~L} 2 / 434 / \mathrm{BU})$ green fluorescent protein (GFP)-expressing strain was generated essentially as described in Wang et al. [31].

\section{Antibodies}

$\beta$-Tubulin antibody was purchased from Santa Cruz Biotechnology (Santa Cruz), and the OmpA antibody was raised in rabbits against the cytosolic domain of OmpA carrying a His-tag. Phalloidin647 was obtained from Thermo Scientific and DAPI (4',6-diamidino-2-phenylindole) from Sigma.

\section{Bioactivity assay}

The assay was performed in black bottom 96-well plates (Greiner). $1.2 \times 10^{4} \mathrm{HeLa}$ cells were seeded per well. Compounds, solubilized in DMSO, were added to final concentrations of $1.6 \mu \mathrm{M}, 8 \mu \mathrm{M}$, and $40 \mu \mathrm{M}$. To the same amount of DMSO and $11.25 \mu \mathrm{M}$ tetracycline (Sigma Aldrich, purity 99\%) negative and positive controls were added, respectively. After $1 \mathrm{~h}$ incubation, cells were infected with $C$. trachomatis at MOI 1 for $24 \mathrm{~h}$ at $35^{\circ} \mathrm{C}$ in media supplemented with $5 \%$ h.i. FBS in the presence of the compounds. The cells were then washed with PBS and fixed with 4\% PFA. After washing, cell nuclei were stained with DAPI (4',6diamidino-2-phenylindole, $0.2 \mathrm{ng} / \mathrm{mL}$ ) and the actin cytoskeleton with Phalloidin647. The analysis was performed with the Operetta high content imaging system (Perkin Elmer) at six pictures per well and 20× magnification. The ratio between HeLa cell surface and the $C$. trachomatis inclusion area was calculated by the system. $11 \times 10^{3}$ Cells have been analyzed, on average. The calculated percentage of inclusion area of the bioactivity assay was used to determine the $\mathrm{IC}_{50}$. A logarithmic trend line was used to calculate the agent concentration at $50 \%$ inclusion surface.

\section{Elementary body progeny assay}

$4 \times 10^{5}$ HeLa cells were seeded in two 12 -well plates (plate A and $B)$, which were treated in the same manner. Treatment of the cells with the compounds and infection with bacteria were performed as described in the bioactivity assay. Plate A (primary infection) was harvested after $24 \mathrm{~h}$ using Laemmli buffer. Forty-eight h after infection, to allow $C$. trachomatis to finalize the developmental cycle, host cells of plate B were lysed with glass beads. The progeny infectious particles were released, and $2 \mu$ of the suspension was used to infect fresh HeLa monolayers in a 12-well plate (plate $\mathrm{C}$, progeny infection). After $24 \mathrm{~h}$ of infection, plate $\mathrm{C}$ was harvested in the same manner as the plate $A$. Cell lysates were analyzed by Western blot using antibodies against $\beta$-tubulin and the chlamydial protein OmpA. The measured OmpA intensities were normalized with the $\beta$-tubulin intensities, where the normalization factor was calculated by dividing the $\beta$-tubulin intensities with the intensity of the $\beta$-tubulin DMSO control.

\section{Supporting information}

1D and 2D NMR spectral data of $\mathbf{1}$ and $\mathbf{2}$ are available as Supporting Information.

\section{Acknowledgements \\ $\nabla$}

We thank Dr. U. Eilers and Dr. C. Schülein-Völk (Biocenter Core Facility "Functional Genomics", University of Würzburg) for their excellent support of the Operetta high content imaging analyses. Financial support was provided by Deutsche Forschungsgemeinschaft awarded (SFB 630-TPA5) to U.H., SFB630-TPB9 to V.K.-P. and T.R. and the Royal Society Starter Grant (115773: Marine symbionts and terrestrial endophytes for industrial biotechnology of novel antibiotics) awarded to R. E. E. We further thank the Egyptian Environmental Affairs Agency (EEAA) for facilitating sample collection along the coasts of the Red Sea. The authors are grateful to R.W.M. van Soest, Faculty of Science, Zoological Museum Amsterdam for taxonomic identification of the sponge sample.

\section{Conflict of Interest}

$\nabla$

The authors declare no conflict of interest.

\section{Affiliations}

${ }^{1}$ Department of Botany II, Julius-von-Sachs Institute for Biological Sciences, University of Würzburg, Würzburg, Germany

${ }^{2}$ Department of Microbiology, Biocenter, University of Würzburg, Würzburg, Germany

${ }^{3}$ Department of Pharmacognosy, Faculty of Pharmacy, Suez Canal University, Ismailia, Egypt

${ }^{4}$ Strathclyde Institute of Pharmacy and Biomedical Sciences, University of Strathclyde, Glasgow, UK

${ }^{5}$ Permanent address: Department of Pharmacognosy, Faculty of Pharmacy, Minia University, Minia, Egypt

\section{References}

1 Thomas TRA, Kavlekar DP, LokaBharathi PA. Marine drugs from spongemicrobe association - a review. Mar Drugs 2010; 8: 1417-1468

2 Hentschel U, Usher KM, Taylor MW. Marine sponges as microbial fermenters. FEMS Microbiol Ecol 2006; 55: 167-177

3 Hertiani T, Edrada-Ebel R, Ortlepp S, van Soest RW, de Voogd NJ, Wray V, Hentschel U, Kozytska S, Müller WE, Proksch P. From anti-fouling to biofilm inhibition: new cytotoxic secondary metabolites from two Indonesian Agelas sponges. Bioorg Med Chem 2010; 18: 1297-1311

$4 \mathrm{Mol}$ VPL, Raveendran TV, Parameswaran PS. Antifouling activity exhibited by secondary metabolites of the marine sponge, Haliclona exigua (Kirkpatrick). Int Biodeter Biodegr 2009; 63: 67-72

5 Faulkner DJ. Marine natural products. Nat Prod Rep 2002; 19: 1-48

6 Blunt JW, Copp BR, Munro MH, Northcote PT, Prinsep MR. Marine natural products. Nat Prod Rep 2005; 22: 15-61

7 Proksch P, Putz A, Ortlepp S, Kjer J, Bayer M. Bioactive natural products from marine sponges and fungal endophytes. Phytochem Rev 2010; 9: 475-489

8 Laport MS, Santos OCS, Muricy G. Marine sponges: potential sources of new antimicrobial drugs. Curr Pharm Biotechnol 2009; 10: 86-105

9 Tsukamoto S, Kato H, Hirota H, Fusetani N. Seven new polyacetylene derivatives, showing both potent metamorphosis-inducing activity in ascidian larvae and antifouling activity against barnacle larvae, from the marine sponge Callyspongia truncate. J Nat Prod 1997; 60: 126-130

10 Youssef D, van Soest R, Fusetani N. New polyacetylenic alcohols with cytotoxic activity from the Red Sea sponge Callyspongia sp. J Nat Prod 2003; 66: 679-687 
11 Uno M, Ohta S, Ohta E, Ikegami S. Callyspongins A and B: novel polyacetylene sulfates from the marine Callyspongia truncate. J Nat Prod 1996; 59: 1146-1148

12 Sera Y, Adachi K, Shizuri Y. A new epidioxy sterol as an antifouling substance from a Palauan marine sponge, Lendenfeldia chondrodes. J Nat Prod 1999; 62: 152-154

13 Youssef DT, Ibrahim AK, Khalifa SI, Mesbah MK, Mayer AM, van Soest RW. New anti-inflammatory sterols from the two Red Sea sponges Scalarispongia species and Callyspongia siphonella. Nat Prod Commun 2009; 5: $27-31$

14 Somani J, Bhullar VB, Workowski KA, Farshy CE, Black CM. Multiple drug-resistant Chlamydia trachomatis associated with clinical treatment failure. J Infect Dis 2000; 181: 1421-1427

15 Stephens RS. The cellular paradigm of chlamydial pathogenesis. Trends Microbiol 2003; 11: 44-51

16 Ray KJ, Zhou ZX, Cevallos V, Chin S, Enanoria W, Lui F, Lietman TM, Porco $T C$. Estimating community prevalence of ocular Chlamydia trachomatis infection using pooled polymerase chain reaction testing. Ophthal Epidemiol 2014; 21: 86-91

17 Fan H. Blindness-causing trachomatous trichiasis biomarkers sighted. Invest Ophthalmol Vis Sci 2012; 53: 2560

18 Ratnam S, Jang D, Gilchrist J, Smieja M, Poirier A, Hatchette T, Flandin JF, Chernesky M. Workflow and maintenance characteristics of five automated laboratory instruments for the diagnosis of sexually transmitted infections. J Clin Microbiol 2014; 52: 2299-2304

19 Sandoz KM, Rockey DD. Antibiotic resistance in Chlamydiae. Future Microbiol 2010; 5: 1427-1442

20 Sharma M, Rudel T. Apoptosis resistance in Chlamydia-infected cells: a fate worse than death? FEMS Immunol Med Microbiol 2009; 55: 154161

21 Beatty WL, Morrison RP, Byrne GI. Persistent chlamydiae: from cell culture to a paradigm for chlamydial pathogenesis. Microbiol Rev 1994; 58: 686-699
22 Hogan RJ, Mathews SA, Mukhopadhyay S, Summersgill JT, Timms P. Chlamydial persistence: beyond the biphasic paradigm. Infect Immun 2004; 72: 1843-1855

23 Salin O, Alakurtti S, Pohjala L, Siiskonen A, Maass V, Maass M, Yli-Kauhaluoma J, Vuorela $P$. Inhibitory effect of the natural product betulin and its derivatives against the intracellular bacterium Chlamydia pneumoniae. Biochem Pharmacol 2010; 80: 1141-1151

24 Horan AC, Shearer MC, Hedge V, Beyazova ML, Brodsky BC, King A, Berrie $R$, Cardaci $K$, Nimeck $M$. A family of novel macrocyclic lactones, the saccharocarcins produced by Saccharothrix aerocolonigenes subsp. antibiotica. I. Taxonomy, fermentation, isolation and biological properties. J Antibiot (Tokyo) 1997; 50: 119-125

25 Gallimore WA, Kelly M, Scheuer PJ. Gelliusterols A-D, new acetylenic sterols from a sponge, Gellius species. J Nat Prod 2001; 64: 741-744

26 Hesse M, Meier H, Zeeh B. Spektroskopische Methoden in der organischen Chemie. 3rd ed. Stuttgart: Thieme Verlag; 1987: 36

27 Umeyama A, Nagano C, Arihara S. Three novel C-21 polyacetylenes from the marine sponge Callyspongia sp. J Nat Prod 1997; 60: 131-133

28 Carballeira NM, Shalabi F. Novel brominated phospholipid fatty acids from the Caribbean sponge Petrosia sp. J Nat Prod 1993; 56: 739-746

29 Wylie JL, Hatch GM, McClarty G. Host cell phospholipids are trafficked to and then modified by Chlamydia trachomatis. J Bacteriol 1997; 179: 7233-7242

30 Gilk SD, Cockrell DC, Luterbach C, Hansen B, Knodler LA, Ibarra JA, SteeleMortimer $O$, Heinzen RA. Bacterial colonization of host cells in the absence of cholesterol. PLoS Pathog 2013; 9: e1003107

31 Wang Y, Kahane S, Cutcliffe LT, Skilton RJ, Lambden PR, Clarke IN. Development of a transformation system for Chlamydia trachomatis: restoration of glycogen biosynthesis by acquisition of a plasmid shuttle vector. PLoS Pathog 2011; 7: e1002258 